\title{
Research of Sports cultural orientation based on Khampa Tibetans leisure activities
}

\author{
Bingsong ZHANG \\ Department of Physical Education \\ Sichuan University for Nationalities \\ Kangding,626001 China
}

\begin{abstract}
Sports cultural orientation of Khampa Tibetans is an important means to study Tibetan cultural development. According statistical findings on Khampa Tibetans leisure activities it reflects the relationship between Khampa Tibetan leisure activities and culture and sports, as well as obtaining harmonious understanding between Khampa Tibetan culture and sports, in addition to building the diverse features of Tibetan sports culture and analysing Khampa Tibetan favorite form of communication and unique culture selectivity on sports culture. It provides a unique perspective for the development of tourism economic and cultural landscape on Khampa Tibetan sports culture.
\end{abstract}

Keywords- national sports; Tibetan culture; Khampa sports culture

\section{INTRODUCTION}

Khampa or kang district known as Kham region, is one of the three ancient region which consists of wei, Tibetan and Kang. Tibetan is a bred in the mountains and steppe nation, mountain, stone and grasslands for Tibetan Traditional Sports offers unique early-type sports equipment and venues [1]. In the magical split of natural geographical environment, Kamba farming and pastoral are great diverse while enhance each other's beauty. Whatever grand folk festival celebrations or small family gathering, everyone will involved in it at Kham. This activities support by interest and culture unity the people's physical and mental and formed a wide and deep charming Kamba sports culture.

\section{INTERPRETATION OF SPORTS CULTURE ON KHAM TIBETAN LEISURE ACTIVITIES}

\section{A. traditional cultural practices of large-scale events}

Kham Tibetan like to gathering in sports. the traditional race meeting such as the "set the slope grassland event " in Qinghai , "Prairie Jockey " in Aba and "Mt International will"in ganzi of sichuang ;"thousands people of guo Zhuang"; wrestling; woman collective tug of war; yak race and more than 20 activities. This activities which Tibetan culture as a core form a unique cultural image upon the social culture, production ways and living conditions reflects the times spirit of the Tibetan people truly and fully [2]. Sports Culture 2011 Mt Kangding April eight Paoma international conference of thousands of pot village, to the mountain to pray activities with national, regional characteristics, can reflect the special sports and cultural orientation Kham Tibetan gatherings. In addition to these traditional Tibetan movements, as well as basketball and other athletic programs are very popular in Tibetan areas, "Basketball has become very fond of the Tibetans." [3].

\section{B. General gatherings and leisure activities}

Kham Tibetan's general gatherings are refers to the parties on enterprises, families, relatives, personal circle of friends and small-scale units .It includes the activities of entertainment pot village, around the mountain within a family member, the prayer wheel, small basketball competition between friends circle, family units farmhouse reception guests activities, etc., All those are entertainment activities which both bodybuilding and enjoying. The self entertainment sports culture in social interaction of Kham Tibetan which combined entertainment with sense of national pride in small range and self entertainment is a perfect fit of spirits and body movements.

Statistics on leisure activities and features Analysis

To get the base of the Kham Tibetan culture movement selection and understanding research, we visits a typical agricultural areas and pastoral village Kangding County, Yulin and Litang County Crane Square, we distribute questionnaires to the population whose age are range 15 to 60 in Kham Tibetan, a total of 1200 copies, back 1192, the recovery rate are $99.3 \%$.we find 29 national sports: horse racing, archery, race yak, Georgia swallow (plus charges, elephant tug of war), wrestling (North Ga), hold the stone (duo plus), Bixiu (shot whistling arrow), the ancient flower (throwing stones) Tibetan chess, guitar tough (hand playing carom), Tibetan martial arts, Tibetan broadsword, climbing, pot Zhuang, tap, harp, to the mountain, kowtowing, turning round, flying rope, pole climbing, Tibetan race, skipping , long jump, shuttlecock kicking, swinging, flying a kite, catch minions (hog) and the baby was Lang (cattle) and sports projects 26: basketball, volleyball, soccer, table tennis, badminton, billiards, tennis, tai chi , hurdles, sprints, middle and long distance, gymnastics, aerobics, diving, swimming, shooting, taekwondo, high jump, long jump, weightlifting, shot put, fencing, marathon, discus, javelin and relay race. We get the choice results of national sports and competitive sports items. National sports results is corresponding on 1-29 while the competitive sports items results is on 1-26 ,and all the corresponding results shown in Figure 1. 


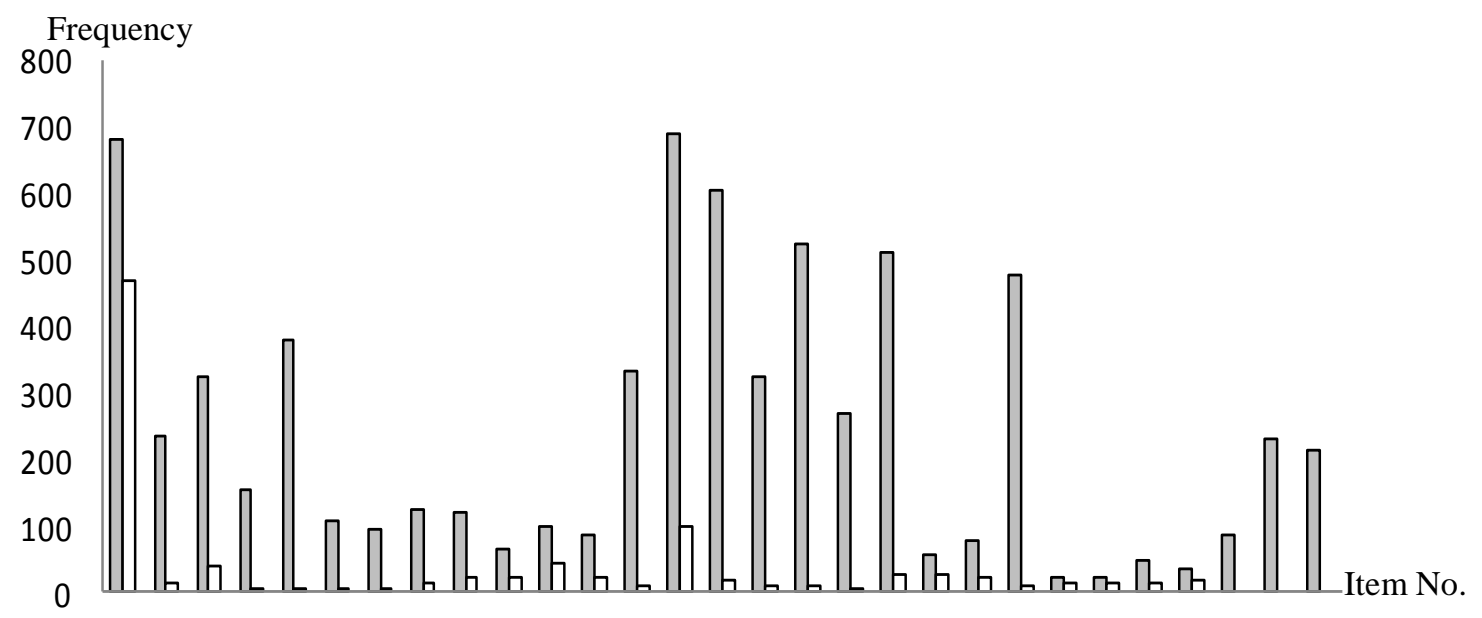

$122 \quad 3 \quad 4 \quad 5 \quad 6 \quad 7 \quad 8 \quad 91011121314151617181920212223242526272829$

\section{National sports}

Figure 1 schematic diagram about the selection of the national sports and sports projects

Figure 1 shows: Kham Tibetan is more inclined to select an item in the local culture that Tibetan national sport, and its ratio is about 7: 3, sorting order of the race, pot Zhuang, basketball, tap, turn the mountain, wrestling, Tibetan race ...... focus tends to race and pans village. Since the germination of the race from the culture appeared, it is natural to take up the entertaining, cultivate people's sentiments, and train a person's character, responsibility and physical health of [4]. Tibetan history records: about AD 729-year celebration of the first race is to be completed in the Samye Monastery, and

Table 1 Top 10 of Kham Tibetan selecting

\begin{tabular}{|c|c|c|c|}
\hline & List & Frequency $(\%)$ & leisure activities \\
\hline 1 & Guo Zhuang & $691(58.0)$ & $\begin{array}{l}\text { festivals, celebrations, wedding celebrations, squares, temples, village } \\
\text { pot pastoral areas, reception entertain guests, leisure and entertainment }\end{array}$ \\
\hline 2 & $\begin{array}{l}\text { Horse } \\
\text { Racing }\end{array}$ & $683(57.3)$ & Jockey Club, Prairie festivals, leisure and entertainment \\
\hline 3 & Tap & $604(50.7)$ & $\begin{array}{l}\text { large-scale performances, festivals and entertainment, folk song and } \\
\text { dance performances }\end{array}$ \\
\hline 4 & $\begin{array}{l}\text { Turn the } \\
\text { mountain }\end{array}$ & $526(44.1)$ & will Kham around Mt (Buddha Day) \\
\hline 5 & $\begin{array}{l}\text { Turning } \\
\text { Jinglun }\end{array}$ & $513(43.0)$ & festive activities of daily living \\
\hline 6 & Tibetan race & $478(40.1)$ & Jockey Club, festive holiday celebration \\
\hline 7 & Basketball & $468(39.3)$ & $\begin{array}{l}\text { for each unit or group of entertainment and games, small-scale } \\
\text { entertainment competitions, fitness activities, interests, activities }\end{array}$ \\
\hline 8 & Wrestling & $379(31.8)$ & holiday celebrations, meetings, post-harvest, daily entertainment \\
\hline 9 & $\begin{array}{l}\text { Climb } \\
\text { moutains }\end{array}$ & $331(27.8)$ & daily fitness activities, festivals cater to needs \\
\hline 10 & Race Yak & $323(27.1)$ & Ongkor Festival and other festivals festive entertainment and games \\
\hline
\end{tabular}


From these items it can clearly be seen standing in groups, sports daily exercise choice in the Kham Tibetan is very prominent, but also it confirms that these groups view their projects gatherings way. Table 1 shows: agricultural areas and pastoral areas in the choice have some differences, which geographical differences and human environment are inextricably relations, agricultural areas are also mainly mountainous, mainly pastoral grasslands; agricultural areas Tibetan culture fusion is more, and grassland is relatively small. In top 10 although there is basketball, but basketball is not festive holiday game or entertainment-sports program. Therefore, in general, Kham Tibetan cultural projects in select sports conscious choice on the potential is consistent with the local culture, geography for the environment is always the first choice.

\section{KHAM TIBETAN CULTURAL CHARACTERISTICS OF SPORTS AND LEISURE ACTIVITIES SELECTED SEQUENCE}

Kham Tibetan in the last election leisure program presents the following characteristics: the trend of the world's cultural diversity of choice; festive holiday to the national convention is as the main leisure activities, it is not to pure sports presentation, but in order to interact with sports and entertainment for sports and cultural characteristics; pious way of thinking and modern means of communication. These features from the sports and cultural point of view can be reflected mainly that Tibetan Kham is rich and full of choice features, and the ability to show the national temperament, physical activity will be to retain the characteristics of the way of communication and heritage.

\section{A. rich, full diversity of leisure activities}

By the choice of the national project of statistical reasons, as shown in Table 2: favorite sports accounted for $34.1 \%$, Tibetan is a universal religious nation [5], and therefore, the influence of religion in the selection of the national sports and cultural projects accounted for $50.7 \%$. Kham Tibetan is caused by their environment, their family and the cultural heritage and other factors, in the choice of the national sports and sports projects, more choices themselves are very familiar, like the Tibetan culture represents the characteristics of the project. In the environmental and cultural impact of agricultural areas and pastoral areas, at this level it also has certain characteristics in common. It is reflected in the national movement for common items like the same high degree of about 1: 1. But that does not mean they do not like sports programs. We also found a large festival in Kham Tibetan festivals and sports programs will not be carried out. In the other one column, it also filled with Tibetan sports and it can reflect positive style, which reflects the Kham Tibetan cultural identity of the nation.

Table 2 the List of cognitive impact of selection of national sports $2(\%)$

\begin{tabular}{cccccc}
\hline & $\begin{array}{c}\text { Favorite } \\
\text { sports }\end{array}$ & Family tradition & $\begin{array}{c}\text { Religious } \\
\text { influence }\end{array}$ & $\begin{array}{c}\text { Like to } \\
\text { appreciate }\end{array}$ & $\begin{array}{c}\text { The impact of } \\
\text { others }\end{array}$ \\
\hline Agricutural Area & 16.4 & 3.1 & 13.5 & 0.8 & 0.1 \\
Pastoral & 17.7 & 10.7 & 37.2 & 0.4 & 0.1 \\
\hline
\end{tabular}

Combined in Table 1, it shows: intense physical exercise programs accounted for $40 \%$, such as horse racing. Religious and cultural projects accounted for $20 \%$, such as mountains and spinning prayer wheels. Entertainment with a dance and artistic characteristics accounted for $20 \%$, such as pot Zhuang, tap. The most extensive project carried out in rural areas are basketball and climbing, while welcome in pastoral areas like basketball. Of course, these items in addition to basketball, but in Kham Tibetan daily life, festivals, sports and cultural programs are all combined with each other, with the circumstances of the particular time and content to determine which projects or to perform a range of games.

\section{B. Show the national temperament in motion}

Horse racing, yak, Tibetan racing, wrestling and other intense physical confrontation with a national sport reflects the Kham Tibetan close to the West in modern sports culture communication, they are embodied in the nation in competitive fighting courage recreation and entertainment temperament. Race and race yak Tibetan people and animals live together in perfect harmony nature while being able to entertain and honor. Tibetan plateau race and wrestle with its own characteristics, national movement aesthetics and pious religious thinking will combine the thinking, the environment and human culture into a three-dimensional one, reflecting the multi-dimensional nature of the Kham Tibetan culture movement. Pot Zhuang, tap, turn the mountain, sports and cultural turning round belong lightweight, reflecting the status ladder Kham sports culture. Zhuang pot and tap dance also has been called dance, but they are also a fitness routine and Tibetan Kham entertainment during the holiday season, it is also a fitness program. Typical characteristics of Mt and turning the wheel of religious and cultural movement strong cultural projects reflect the pious ideological guidance of physical activity.

Table 3 shows: 10 average mean score of 4.19 selected that awareness is high Tibetan national movement for the selected cultural projects. There are six more than 4.19 in. Sports culture in choosing projects are both pure religious, but also intense confrontational, relaxed lifestyle, as well as recreation and fitness combined with each other. At the same time, basketball is undoubtedly not be fully demonstrated the qualities of the nation, therefore, it means that only 3.26 , but 
it also reflects a certain position in the Kham Tibetan basketball sports culture.

Table3 motion perception shows the nation reflecting the temperament of the project in table $(n=120)$

\begin{tabular}{cccccccc}
\hline & $\begin{array}{c}\text { Much } \\
\text { (5points) }\end{array}$ & $\begin{array}{c}\text { more }(4 \\
\text { points) }\end{array}$ & $\begin{array}{c}\text { General }(3 \\
\text { points) }\end{array}$ & $\begin{array}{c}\text { less }(2 \\
\text { points) }\end{array}$ & $\begin{array}{c}\text { less (1 } \\
\text { point) }\end{array}$ & $\begin{array}{c}\text { score Mean } \\
\text { Sort }\end{array}$ \\
\hline Race horse & 81 & 42 & 3 & 0 & 0 & 4.85 & 1 \\
Race yak & 71 & 25 & 27 & 11 & 4 & 4.68 & 2 \\
Mountaineering & 53 & 38 & 18 & 28 & 21 & 4.57 & 3 \\
Guozhuang & 65 & 31 & 18 & 17 & 3 & 4.50 & 4 \\
Tibetan race & 63 & 42 & 13 & 7 & 0 & 4.47 & 5 \\
Turning Jinglun & 62 & 27 & 15 & 27 & 0 & 4.31 & 6 \\
Tap & 48 & 34 & 10 & 21 & 12 & 3.83 & 7 \\
Wrestling & 37 & 30 & 32 & 19 & 10 & 3.74 & 8 \\
Turn moutains & 62 & 12 & 17 & 14 & 7 & 3.70 & 9 \\
Basketball & 13 & 43 & 17 & 28 & 47 & 3.26 \\
\hline
\end{tabular}

\section{National cultural exchanges which have physical activity patterns characteristic}

Physical activity is the basic characteristic of sport culture, in geographical background, with national tradition featuring [6]. Kham Tibetan culture movement is similar to physical activity, and it is based on physical activity by means of exchanges and cooperation with others, make friends. No matter where you come from, as long as you go to the Tibetan, Zhuang warm pot makes you relax and make you cheerful melodies intoxicated, climbing a sense of accomplishment will make you linger, prairie horse racing and other activities reflects the enthusiasm of the Tibetan people and heroic. Communication physical activity makes the experience of those who feel the Tibetan culture, active sports, rich and pious. Through tourism development, Kham's youthful glow sports culture immortal vigor. Table 4 selected horse racing, yak, etc. are groups of activities, and sports exchanges are given special cultural identities in motion.

\section{CONCLUSIONS}

Kham Tibetan ethnic culture and sports like sports culture has its common cultural property, they are the result of the development of human civilization. We are not just from the basic classification, the basis for defining the national movement to study other aspects of culture, we should have a special perspective and in line with national identity research ideas. If selective Kham Tibetan culture movement of the project is the choice of Kham Tibetan unconscious behavior, you need to select the overall analysis of the project. National Geographic feature Kham region, characteristic of the human environment, sport and cultural diversity, rich cultural features are extracted in a selective Kham Tibetan movement. Overall, Kham Tibetan cultural projects in the choice movement reflects the combination of entertainment and athletics, combined with the nation and the world combined, religion and sports culture, dance harmony between man and animal, agricultural areas and pastoral areas complement each other, rhythm combining fast and slow, the overall characteristics of the individual and the collective win-win movement of cultural cooperation.

\section{ACKNOWLEDGEMENTS}

Fund: 2014 annual research Sichuan Provincial Education Department (14SB0276). Sichuan Provincial Department of Education 2013 annual research (13SB0189).

\section{REFERENCE}

[1] Lei Wei. Study Tibetan Traditional Sports Culture [J] Tibetan Studies, 2009 (3): 116.

[2] Ding Linghui. Tibetan identity and cultural heritage of sports[J] Southwest University for Nationalities (Humanities and Social Sciences Edition)2008. (10): 26.

[3] Sina Sports. Basketball popular Tibetan - tells the story of basketball related Diqing [EB / OL] [2007-02-15] http://sports.sina.com.cn/s/2007-02. -15 / 10261107102s.shtml.

[4] Yang Yingjie. Maqu Jockey cultural function [J] Physical Institute of Shanxi Normal University, 2010 (4): 66.

[5] Shi Sheng. Tibetan religious art of dance [J] Southwest University of Science and Technology (Philosophy and Social Sciences), 2007 (10): 77.

[6] Ma Jing, Yang Gangshan. Sports culture is instrumental and human unity [J] Sport and Science, 2005 (11): 20. 